\title{
Results of coronary artery spasm treatment after cardiac surgery procedures
}

\author{
DS Tungusov*, II Chernov, DG Tarasov, AV Pavlov, DA Kondratyev, RA Urtaev, W Pasyuga \\ From World Society of Cardiothoracic Surgeons 25th Anniversary Congress, Edinburgh \\ Edinburgh, UK. 19-22 September 2015
}

\section{Background/Introduction}

Postoperative coronary artery spasm (CAS) is an infrequent life-threatening event after cardiac surgery. We have suggested to cross clamp aorta for short time and to inject nitrates into the aortic root in case of suspicion of CAS. It enable us to deliver nitrates especially into coronary arteries during operation (patent RU 2552890). Another method is conventional coronary angiography with injection of nitrates.

\section{Aims/Objectives}

The purpose of this study was to compare two methods of treatment CAS.

\section{Method}

Between January 2013 and December 2014 we prospectively collected data from a consecutive cohort of 3452 patients who underwent cardiac surgery. CAS was registered in $60(1,7 \%)$ patients and was associated with new ST-segment changes on electrocardiogram, ventricular arrhythmias, cardiac arrest or hemodynamic collapse, new changes in regional wall motion, or any other relevant suspect of myocardial ischemia during operation and postoperative intensive care unit stay were included. Patients with non-patent grafts and with abnormal coronary blood flow surgically caused were excluded. The method of CAS treatment was based on surgeon decision.

\section{Results}

22 patients underwent coronary angiography after operation. Injection of nitrates was performed into coronary arteries or grafts (group 1). In 38 cases injection of nitrates into aortic root was made on short time cross clamp (group 2). Perioperative myocardial infarction

Federal Centre for Cardiovascular Surgery, Astrakhan, 414024, Russia
(MI) was found in 13 (59.9\%) cases (group 1), 6 (15.8\%) cases (group 2) $(\mathrm{p}<0.0001)$. A significant difference was observed between the two groups in the length of hospitalization $(\mathrm{p}<0.05)$, length of ICU stay $(\mathrm{p}<0.05)$. The in-hospital mortality in the first group was $2(9.1 \%)$ in the second group the absence of mortality was registered.

\section{Discussion/Conclusion}

Early suspicion of CAS and intraoperative injection of nitrates into aortic root enables to decrease MI, in-hospital mortality, ICU and in-hospital stay.

Published: 16 December 2015

doi:10.1186/1749-8090-10-S1-A51

Cite this article as: Tungusov et al: Results of coronary artery spasm treatment after cardiac surgery procedures. Journal of Cardiothoracic Surgery 2015 10(Suppl 1):A51.
Submit your next manuscript to BioMed Central and take full advantage of:

- Convenient online submission

- Thorough peer review

- No space constraints or color figure charges

- Immediate publication on acceptance

- Inclusion in PubMed, CAS, Scopus and Google Scholar

- Research which is freely available for redistribution
() Biomed Central 